\title{
Low-Density Lipoprotein Receptor-deficient Mice Are Protected Against Lethal Endotoxemia and Severe Gram-negative Infections
}

\author{
Mihai G. Netea, Pierre N.M. Demacker, Bart Jan Kullberg, Otto C. Boerman, ${ }^{\star}$ Ineke Verschueren, Anton F.H. Stalenhoef, \\ and Jos W.M. van der Meer \\ Division of General Internal Medicine, Department of Medicine and *Department of Nuclear Medicine, University Hospital Nijmegen \\ 6500 HB Nijmegen, The Netherlands
}

\begin{abstract}
Lipoproteins can bind lipopolysaccharide (LPS) and decrease the LPS-stimulated production of pro-inflammatory cytokines. We investigated the effect of increased plasma concentrations of low-density-lipoproteins (LDL) on survival and cytokine production after a lethal challenge with either LPS or live Gram-negative bacteria in LDL receptor deficient mice (LDLR-I-). The LDLR-I- mice challenged with LPS had an eightfold increased $\mathrm{LD}_{50}$ when compared with the wild type controls $(\mathrm{C} 57 \mathrm{Bl} / 6 \mathrm{~J})$, while tumor necrosis factor $\alpha(\mathrm{TNF} \alpha)$ and interleukin-1 $\alpha$ (IL-1 $\alpha)$ plasma concentrations were decreased twofold. LDLR-Imice had significantly lower and delayed mortality than control mice after infection with Klebsiella pneumoniae. No differences in the outgrowth of bacteria in the organs were present between the two groups, while circulating cytokine concentrations were decreased twofold in LDLR $-I-$ mice. In contrast, the LPS-stimulated in vitro production of cytokines by peritoneal macrophages of LDLR $-I-$ mice was significantly increased compared with controls. This increase was associated with enhanced specific binding of LPS to the macrophages of LDLR $-/-$ mice. In conclusion, endogenous LDL can protect against the lethal effects of endotoxin and Gram-negative infection. At least part of this protection is achieved through decreased in vivo production of pro-inflammatory cytokines, in spite of increased cytokine production capacity. (J. Clin. Invest. 1996. 97:13661372). Key words: lipopolysaccharide - gram-negative infection - tumor necrosis factor • interleukin-1 - low-density lipoproteins.
\end{abstract}

\section{Introduction}

Mammals infected with Gram-negative bacteria may develop a severe syndrome characterized by hypotension, disseminated intravascular coagulation, and renal, hepatic and cerebral

This work was presented in part at the 35th Interscience Conference on Antimicrobial Agents and Chemotherapy, San Francisco, CA, September 20, 1995 (Abstract G96).

Address correspondence to Jos W.M. van der Meer; Department of Medicine (541), University Hospital Nijmegen, P.O. Box 9101, 6500 HB Nijmegen, The Netherlands. Phone: 24-3614763; FAX: 243541734.

Received for publication 25 July 1995 and accepted in revised form 3 January 1995.

J. Clin. Invest.

(C) The American Society for Clinical Investigation, Inc.

0021-9738/96/03/1366/07 \$2.00

Volume 97, Number 6, March 1996, 1366-1372 damage. Most of these deleterious effects can be mimicked by infusion of endotoxin, a lipopolysaccharide (LPS) component of the cell wall of Gram-negative bacteria (1). Binding of LPS to various receptors on leukocytes triggers the production and release of proinflammatory cytokines as tumor necrosis factor $\alpha(\mathrm{TNF} \alpha)$, interleukin- $1 \alpha$ (IL-1 $\alpha)$ and IL-1 $\beta$. In experimental models, treatment of animals with anti-TNF antibodies attenuates the lethal effects of endotoxin or Gram-negative bacteria $(2,3)$. A protective effect can also be obtained by treatment with either of the natural antagonists of TNF or IL-1, soluble TNF receptors or IL-1 receptor antagonist $(4,5)$. Thus, these cytokines are thought to play a central role in the pathophysiology of sepsis.

Once LPS enters the circulation, initial interactions with LPS-binding protein (LBP) and lipoproteins play a critical role in subsequent stimulation of pro-inflammatory cytokine synthesis. The LPS-LBP complex is bound by CD14, the cellular receptor for $\mathrm{LBP}$, and this binding stimulates macrophages to release pro-inflammatory cytokines $(6,7)$. Recent studies also suggest that LBP may facilitate the binding of LPS not only to CD14, but also to lipoproteins (8), either by direct action of LBP or by a two-step reaction in which LPS is first transferred to sCD14 and subsequently to HDL (9). In plasma, LPS bind to the various types of lipoproteins: high-density lipoproteins (HDL) (10), low-density lipoproteins (LDL) (11), very-lowdensity lipoproteins (VLDL) (12) and chylomicrons (13). Formation of LPS-lipoproteins complexes greatly reduces the binding of LPS to macrophages $(14,15)$. In vitro, this results in decreased production and release of the pro-inflammatory cytokines TNF, IL-1 and IL-6 $(16,17)$, and a subsequent loss of LPS toxicity.

The potential protective effect of lipoproteins against LPStoxicity in vivo has been investigated in recent studies. Preincubation of LPS with lipoproteins prior to injection into animals decreased the mortality (10), while the in vivo infusion of lipoproteins markedly reduced the cytokinemia and mortality after LPS administration (18). Transgenic mice that express human apolipoprotein A-1 at high levels and thus have elevated plasma HDL concentrations are protected against LPS challenge (19). In contrast, hypolipidemic mice are more sensitive to the toxic effects of endotoxin (20).

All these studies have shown a protection by lipoproteins against LPS effects, while only one recent study has reported that hyperlipoproteinemia may beneficially influence severe infections with live microorganisms (21). In a rat model of cecal ligation and puncture, infusion of exogenous chylomicrons reduced both circulating LPS and TNF concentrations and mortality. However, no data regarding the effect of endogenously elevated lipoprotein concentrations on severe infections have been reported. In the present study, we assessed the effects of a lethal LPS challenge and a lethal Gram-negative infection with Klebsiella pneumoniae in the recently developed 
low density lipoprotein receptor knockout mice (LDLR-/-). These LDLR-/- mice have a markedly increased plasma cholesterol concentration compared with the wild-type controls, due to a 7-9-fold increase in intermediate density lipoproteins (IDL) and LDL (22). To study the mechanisms involved in the lipoprotein-induced protection we assessed the bacterial outgrowth in the organs and the cytokine response during infection. In addition, we studied the cytokine production capacity by the peritoneal macrophages of the LDLR-/and control mice.

\section{Methods}

Animals. Homozygous C57B1/6J mice lacking low density lipoprotein receptors (LDLR-/-) and wild-type littermates were obtained from the Jackson Laboratory (Bar Harbor, ME) as mating pairs, and bred in our local facility. For the experiments, $6-8$ weeks old mice, weighing 20-25 grams, were used. The animals were fed standard laboratory chow (Hope Farms, Woerden, the Netherlands) and housed under specific pathogen-free conditions. The experiments were approved by the ethical committee on animal experiments of the Catholic University Nijmegen.

Lethal endotoxemia model. Lipopolysaccharide (LPS; Escherichia coli serotype O55:B5) was obtained from Sigma Chemical Co. (St. Louis, MO). Groups of LDLR-/- and C57Bl/6J mice were injected i.v. in the retroorbital plexus (after anesthetizing with ether) with various amounts of LPS $(0.25-2.5 \mathrm{mg} / \mathrm{mouse}) .90 \mathrm{~min}$ after challenge with LPS, five animals from each group were anesthetized with ether and bled from the retroorbital plexus for measurement of $\mathrm{TNF} \alpha$ circulating concentrations. Another five animals per group were bled $4 \mathrm{~h}$ after LPS for measurement of IL- $1 \alpha$ and IL- $1 \beta$ circulating concentrations. In the remaining mice (at least 5 animals/group), survival was assessed daily for $7 \mathrm{~d}$.

Lethal cytokinemia model. To investigate the role of TNF and IL-1 in the LPS-induced mortality, LDLR $-/-$ and control mice received a single i.v. injection of recombinant human TNF $\alpha(50 \mu \mathrm{g} /$ mouse) (kindly provided by Dr. G. Adolf, Ernst-Boehringer Institut, Vienna, Austria), recombinant human IL-1 $\alpha$ (10 $\mu \mathrm{g} / \mathrm{mouse})$ (kindly provided by Dr. P. Lomedico, Hoffmann-LaRoche, Nutley, NJ), or a combination of both. Several combinations of recombinant cytokines were used in different experiments: $10 \mu \mathrm{g}$ TNF $\alpha$ with $1 \mu \mathrm{g}$ IL- $1 \alpha, 20$ $\mu \mathrm{g}$ TNF $\alpha$ with $5 \mu \mathrm{g}$ IL- $1 \alpha$, and $50 \mu \mathrm{g}$ TNF $\alpha$ with $20 \mu \mathrm{g}$ of IL- $1 \alpha$. Survival was assessed every $12 \mathrm{~h}$ for $2 \mathrm{~d}$.

Klebsiella pneumoniae infection. Klebsiella pneumoniae (ATCC 43816), a strain that produces a lethal infection in normal mice, was injected i.v. in the retroorbital plexus $\left(10^{6}-10^{7} \mathrm{CFU} / \mathrm{mouse}\right)$ into LDLR $-/-$ and control mice $\left(\mathrm{LD}_{50} 8 \times 10^{5} \mathrm{CFU} / \mathrm{C} 57 \mathrm{Bl} / 6 \mathrm{~J}\right.$ mouse). To assess whether the same protection is obtained in a more sustained model of infection, K. pneumoniae $10^{6} \mathrm{CFU} /$ mouse was injected intramuscularly (i.m.) $\left(\mathrm{LD}_{50} 5 \times 10^{5} \mathrm{CFU} / \mathrm{C} 57 \mathrm{Bl} / 6 \mathrm{~J}\right.$ mouse) into the left thigh muscle of the animals as described (23). Survival was assessed daily for $14 \mathrm{~d}$, in groups of at least 18 (i.v. infection) or 9 animals (i.m. infection). The surviving animals were sacrificed on day 28 of infection. After $90 \mathrm{~min}$ and $4 \mathrm{~h}$, subgroups of five mice were killed and blood was collected from retroorbital plexus for the measurement of cytokine concentrations. The outgrowth of the microorganisms from the blood, liver, spleen and kidneys of the animals was quantified $24 \mathrm{~h}$ after the injection of K. pneumoniae. The organs were removed aseptically, weighed, and homogenized in sterile saline in a tissue grinder. Serial dilutions of the homogenized tissues or blood $(0.1 \mathrm{ml})$ were plated on sheep blood agar, and CFU were counted after overnight incubation at $37^{\circ} \mathrm{C}$.

To determine the circulating LPS concentrations, in a separate set of experiments groups of $10 \mathrm{LDLR}-1-$ and control mice were infected i.v. or i.m. with $10^{6} \mathrm{CFU}$ K. pneumoniae as described above. 90 min and $4 \mathrm{~h}$ after infection, groups of five animals were anesthetized and blood collected by intracardiac puncture into 5-ml pyrogen-free plastic vials (Falcon; Becton-Dickinson Labware, Lincoln Park, NJ) containing $25 \mathrm{IU}$ of pyrogen-free heparin. The tubes were centrifuged at $200 \mathrm{~g}$ for $10 \mathrm{~min}$ and plasma was collected and stored at $-70^{\circ} \mathrm{C}$ until assay.

Ex vivo cytokine production. Resident peritoneal macrophages were harvested by rinsing the peritoneal cavity aseptically with cold PBS containing $0.38 \%(\mathrm{wt} / \mathrm{vol})$ sodium citrate. After centrifugation for $10 \mathrm{~min}, 1800 \mathrm{cpm}$, at $4^{\circ} \mathrm{C}$, cells were resuspended in RPMI 1640 (Dutch modification; Flow Laboratories, Irvine, UK), containing $1 \mathrm{mM}$ pyruvate, $2 \mathrm{mM}$ L-glutamine and $100 \mu \mathrm{g} / \mathrm{ml}$ gentamicin. $10^{5}$ cells/well were cultured in 96-well microtiter plates (Costar Corporation, Cambridge, MA) in RPMI medium (final volume $200 \mu \mathrm{l}$ ), with or without LPS at a final concentration of $1 \mu \mathrm{g} / \mathrm{ml}$. No plasma or serum was added to the culture medium. The supernatants were collected after $24 \mathrm{~h}$ of incubation at $37^{\circ} \mathrm{C}$, and stored at $-70^{\circ} \mathrm{C}$ until assay. To the remaining macrophages, $200 \mu \mathrm{l}$ RPMI 1640 was added, and the cells were disrupted by three freeze-thaw cycles to determine the cell-associated cytokine contents. The samples were stored at $-70^{\circ} \mathrm{C}$ until cytokine measurements.

The cytokine production capacity of peritoneal macrophages was also measured after stimulation by heat-killed $\left(100^{\circ} \mathrm{C}, 30 \mathrm{~min}\right)$ Staphylococcus aureus (ATCC 25923). The suspension was washed three times in RPMI (final concentration $2 \times 10^{7} \mathrm{CFU} / \mathrm{ml}$ ). $100 \mu$ l suspension containing $10^{6}$ microorganisms in RPMI were added to $10^{5}$ peritoneal macrophages in 96-well microtiter plates and the cells were incubated $24 \mathrm{~h}$ at $37^{\circ} \mathrm{C}$. The samples were obtained and stored at $-70^{\circ} \mathrm{C}$ until cytokine measurements, as described above.

Cytokine measurements. TNF $\alpha, \mathrm{IL}-1 \alpha$ and IL- $1 \beta$ concentrations were determined using specific radioimmunoassays (RIAs) developed in our laboratory (24). Briefly, standards and samples were diluted in RIA-buffer (per liter: $10 \mathrm{mM} \mathrm{Na} \mathrm{HPO}_{4} \cdot 2 \mathrm{H}_{2} \mathrm{O} ; 12 \mathrm{mM}$ EDTA; $1 \mathrm{ml}$ sodium-azide $(20 \% \mathrm{wt} / \mathrm{vol}) ; 2.5$-gram bovine serum albumin fraction IV (Sigma Chemical Co., St. Louis, MO); $1 \mathrm{ml}$ Triton X-100; $25 \mathrm{ml}$ aprotinin solution (Trasylol, containing 10,000 inhibitor units per milliliter, Bayer BV, Mydrecht, The Netherlands) diluted with deionized water milli-Q, $\mathrm{pH}$ 7.4. $100 \mu \mathrm{l}$ of an appropriate monospecific rabbit antiserum against the respective mouse cytokine was added to $100 \mu \mathrm{l}$ of samples and standards. After vortexing, the tubes were incubated for $24 \mathrm{~h}$ at $4^{\circ} \mathrm{C}$, followed by addition of $100 \mu \mathrm{l}$ of the respective ${ }^{125}$ I-labeled tracers. After $20 \mathrm{~h}, 750 \mu \mathrm{l}$ RIA buffer containing $9 \%(\mathrm{wt} / \mathrm{vol}$ ) polyethylene-glycol 6000 , and $3 \%$ (vol/vol) goat antirabbit IgG was added. The tubes were incubated for $20 \mathrm{~min}$ at room temperature and then centrifuged at $1,500 \mathrm{~g}$ for $15 \mathrm{~min}$. Supernatants were discarded carefully and quickly drained on absorbent paper. Remaining radioactivity was counted in a gamma-counter. The radioactivity in control tubes (the non-specific binding activity) was substracted from samples and standards. Detection limits were between 0.02 and $0.04 \mathrm{ng} / \mathrm{ml}$. The mean of duplicate determinations was calculated for each sample. The accuracy of the cytokine assays was determined using reference preparations: murine recombinant TNF $\alpha$, IL$1 \alpha$, and IL-1 $\beta$ obtained from the National Institute of Biological Standards and Control (NIBSC, Hertfordshire, UK). Using various batches of tracers the bias of all cytokine-assays was $<20 \%$; interassay precision ranged between 10 and $13 \%$ depending on the concentration $(n=22)$.

LPS measurements. Plasma samples were diluted $1 / 100$ and $1 / 600$ with apyrogenic saline and heated at $75^{\circ} \mathrm{C}$ for $5 \mathrm{~min}$ before the limulus assay to remove the effect of serum inhibitors. LPS was determined in platelet-rich plasma by a chromogenic limulus amoebocyte lysate assay (Endosafe Inc., Charleston, SC).

Radioactive labeling of LPS. E. coli O55:B5 LPS was labeled with tritium as described previously (25) with minor modifications. Briefly, LPS $(5 \mathrm{mg} / \mathrm{ml})$ was oxidized with sodium periodate $(1.5 \mathrm{mg} /$ $\mathrm{ml}$ ) in $50 \mathrm{mM}$ acetate buffer, $\mathrm{pH} 4.0$, during $24 \mathrm{~h}$. The remaining periodate was destroyed with ethylene glycol and the LPS was bufferchanged and concentrated in an Amicon concentrator (molecular cut-off $10,000 \mathrm{Da}$ ). $10 \mathrm{mCi}\left[{ }^{3} \mathrm{H}\right]$ sodium borohydride (specific activity 
$21 \mathrm{Ci} / \mathrm{mmol})$ was added to the oxidized LPS $(5 \mathrm{mg} / \mathrm{ml})$ in $1 \mathrm{mM}$ Tris$\mathrm{HCl}, \mathrm{pH}$ 8.0. After a $2 \mathrm{~h}$ incubation at room temperature, the reaction was terminated by the addition of $25 \mathrm{mg}$ nonradioactive sodium borohydride. The tritiated LPS was purified on a PD-10 column (Pharmacia, Woerden, The Netherlands). Subsequently, the unincorporated ${ }^{3} \mathrm{H}$ was removed by repeated concentration in an Amicon concentrator. Elution of the ${ }^{3} \mathrm{H}$-labeled LPS preparation on a PD-10 column indicated that more than $95 \%$ of the ${ }^{3} \mathrm{H}$-label was associated with LPS both in the fresh preparation, as well as in the preparation incubated overnight at room temperature (the temperature of the incubation in the binding studies). The specific activity of this ${ }^{3} \mathrm{H}$-LPS was 16,000 $\mathrm{cpm} / \mu \mathrm{g}$.

Binding of radiolabeled LPS to peritoneal macrophages. Peritoneal macrophages from LDLR $-1-$ and $\mathrm{C} 57 \mathrm{Bl} / 6 \mathrm{~J}$ mice were collected as described above, and $10^{6}$ peritoneal macrophages were incubated in $100 \mu \mathrm{l}$ RPMI 1640 in $0.5 \mathrm{ml}$ Eppendorf plastic cups. No plasma or serum was present in the system. Increasing amounts of $\left[{ }^{3} \mathrm{H}-\mathrm{LPS}\right]$ $(10,000-100,000 \mathrm{cpm})$ were added and the cells were incubated at room temperature for $45 \mathrm{~min}$ (26). Cells were spun down $(2,000 \mathrm{~g}, 5$ min), washed twice in $100 \mu \mathrm{l}$ RPMI, solubilized in scintillation fluid and counted in a $\beta$-counter. Nonspecific binding was determined in the presence of a large excess of nonradioactive LPS. Specific binding of LPS was defined as the difference between total and nonspecific binding.

Determination of plasma lipids. Cholesterol and triglycerides were determined by enzymatic methods on a Hitachi 747 analyzer.

Statistical analysis. Survival data were analyzed using the KaplanMeyer log rank test (27). Differences in concentrations of cytokines and in organ counts of the microorganisms were analyzed using the Kruskall-Wallis test (28). Differences were considered significant at $P<0.05$. All experiments were performed at least twice.

\section{Results}

Lethal endotoxemia model. Plasma cholesterol concentrations are presented in Table I. The total cholesterol concentrations were fourfold higher in LDLR $-/-$ mice at all the time points tested. The plasma triglyceride concentrations differed only marginally in the two mouse strains both $90 \mathrm{~min}$ $(0.67 \pm 0.13$ vs. $0.62 \pm 0.09 \mathrm{mmol} /$ liter, $P>0.05)$ and $4 \mathrm{~h}$ $(0.50 \pm 0.07$ vs. $0.42 \pm 0.06 \mathrm{mmol} / \mathrm{liter}, P>0.05)$ after LPS. The survival of the LDLR $-/-$ mice was significantly increased when compared with $\mathrm{C} 57 \mathrm{Bl} / 6 \mathrm{~J}$ mice, the estimated endotoxin $\mathrm{LD}_{50}$ dose being 8-times higher $(P<0.001)$ (Fig. 1$)$. Mortality occurred in the first $48 \mathrm{~h}$ after endotoxin administration, without further mortality during the next days of the follow-up. Plasma concentrations of TNF $\alpha$ were significantly lower in LDLR - / - mice 90 min after LPS administration, than in control animals $(1.5 \pm 0.5$ vs. $3.7 \pm 0.9 \mathrm{ng} / \mathrm{ml}, P<0.02)$ (Fig. 2$)$. Four hours after the endotoxin challenge, IL- $1 \alpha$ concentrations were also lower in LDLR $-/-$ mice $(60 \pm 21$ vs. $106 \pm 26$ $\mathrm{pg} / \mathrm{ml}, P<0.05)$, while no differences in IL-1 $\beta$ concentrations were detected ( $36 \pm 9$ vs. $37 \pm 9 \mathrm{pg} / \mathrm{ml}, P>0.05$ ) (Fig. 2).

Lethal cytokinemia model. To investigate whether the protection to a lethal injection of endotoxin is due to decreased susceptibility to proinflammatory cytokines, mice were injected i.v. with pro-inflammatory cytokines. The administration of either $50 \mu \mathrm{g}$ recombinant human TNF $\alpha$ or $10 \mu \mathrm{g}$ IL- $1 \alpha$ did not induce any mortality. After the administration of a combination of these cytokines, no protection by the high lipoprotein concentrations of LDLR-/- mice was observed. The mortality was $0 \%$ in both mouse strains when a combination of $10 \mu \mathrm{g}$ of TNF $\alpha$ and $1 \mu \mathrm{g}$ IL- $1 \alpha$ was injected. When a combination of $20 \mu \mathrm{g}$ TNF $\alpha$ with $5 \mu \mathrm{g}$ IL-1 $\alpha$ was injected the mortality

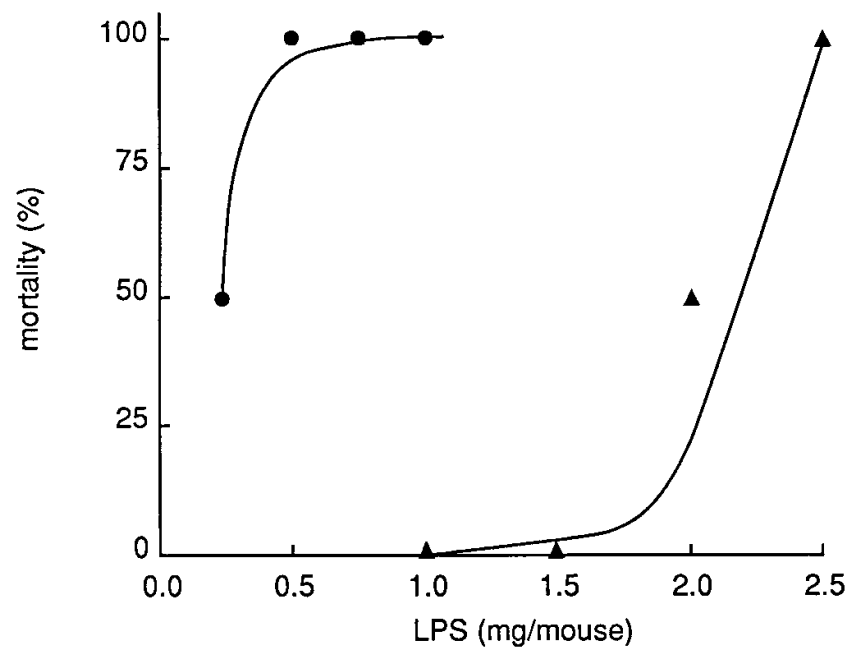

Figure 1. Survival of LDLR -/- ( $\mathbf{\Delta})$ and $\mathrm{C} 57 \mathrm{Bl} / 6 \mathrm{~J}$ mice $(\bullet)$ after LPS challenge. Groups of at least five animals received an intravenous LPS challenge with the dosages shown on the $\mathrm{x}$-axis and the outcome was recorded as percentage mortality after $48 \mathrm{~h}$. LDLR-/mice had a significantly improved survival when compared with the control animals.

was $20 \%$ in LDLR $-/-$ mice and $33 \%$ in the C57Bl/6J mice $(P>0.05)$, and when a combination of $50 \mu \mathrm{g}$ TNF $\alpha$ with $10 \mu \mathrm{g}$ IL-1 $\alpha$ was injected the mortality was $80 \%$ in LDLR-/- mice, and $91 \%$ in controls $(P>0.05)$. The mortality occurred exclusively during the first $48 \mathrm{~h}$.

Klebsiella pneumoniae infection. Cholesterol concentrations during $K$. pneumoniae infection decreased in both strains of mice. However, they remained significantly higher in LDLR-/mice than in control mice (Table I). No significant differences in triglyceride levels $90 \mathrm{~min}$ after infection were found between the $\mathrm{LDLR}-/-$ and $\mathrm{C} 57 \mathrm{Bl} / 6 \mathrm{~J}$ mice $(0.79 \pm 0.11$ vs.

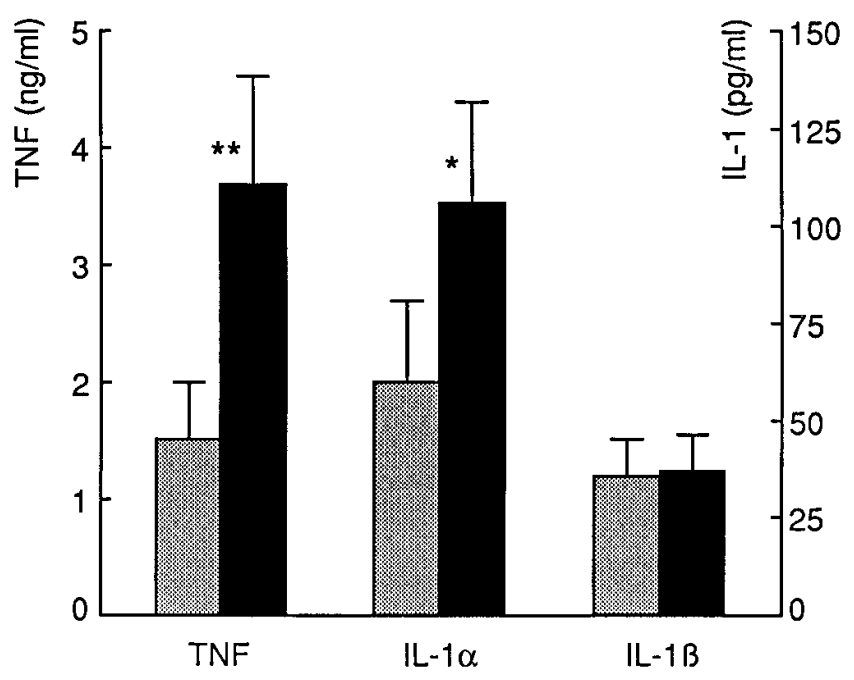

Figure 2. Plasma cytokine concentrations in LDLR-/- (shaded columns) and control mice (black columns) after an intravenous injection with $1 \mathrm{mg}$ LPS. The plasma concentrations of both TNF (90 min after the LPS challenge) and IL-1 $\alpha$ ( $4 \mathrm{~h}$ after LPS challenge) were significantly decreased in LDLR $-/-$ mice when compared with control mice. No differences in IL-1 $\beta$ plasma concentrations were detected $4 \mathrm{~h}$ after LPS was injected. ${ }^{*} P<0.05 ;{ }^{*} P<0.02$. 
$0.75 \pm 0.06 \mathrm{mmol} /$ liter, $P>0.05)$. However, $4 \mathrm{~h}$ after infection the triglycerides concentrations were slightly higher in LDLR $-/-$ mice than controls $(0.79 \pm 0.21$ vs. $0.51 \pm 0.07 \mathrm{mmol} /$ liter, $P<0.05)$. After i.v. injection of $10^{7} \mathrm{CFU}$ of $\mathrm{K}$. pneumoniae, LDLR - / - mice showed a delayed and decreased mortality $(70 \%)$ compared with control animals $(100 \%, P<0.01)$ (Fig. 3). After an i.v. infection with $10^{6} \mathrm{CFU}$, only $42 \%$ of LDLR $-/-$ mice died, in comparison with $67 \%$ of the C57Bl/ $6 \mathrm{~J}$ mice $(P<0.05)$ (Fig. 3). In the K. pneumoniae infection models studied, no deaths occurred after $14 \mathrm{~d}$ of infection. No differences in K. pneumoniae outgrowth in the organs of the two groups $24 \mathrm{~h}$ after infection was observed (Table II). Also, quantitative blood cultures revealed no differences between the two mouse strains (Table II). However, the LPS concentrations in LDLR-/- mice tended to be lower when compared with $\mathrm{C} 57 \mathrm{Bl} / 6 \mathrm{~J}$ mice, in both strains reaching high values $90 \mathrm{~min}$ after i.v. injection of Klebsiella, and decreasing at $4 \mathrm{~h}$ (Table III). TNF $\alpha$ concentrations in the plasma of LDLR-/mice measured $90 \mathrm{~min}$ after infection were lower compared with control mice, although statistical significance was not reached $(0.45 \pm 0.46$ vs. $0.81 \pm 0.61 \mathrm{ng} / \mathrm{ml}, P>0.05)$. Concentrations of IL- $1 \alpha$ in the plasma of LDLR $-/-$ mice were lower as compared with control mice at $4 \mathrm{~h}$ after infection (56 $\pm 40 \mathrm{vs}$. $114 \pm 9 \mathrm{pg} / \mathrm{ml}, P<0.04)$; only marginally lower IL-1 $\beta$ was detected in LDLR $-/-$ mice ( $55 \pm 21$ vs. $78 \pm 13 \mathrm{pg} / \mathrm{ml}, P>0.05$ ).

When the more sustained $K$. pneumoniae infection was induced by intramuscular injection of $10^{6} \mathrm{CFU}$, the survival in the LDLR $-/-$ group was $56 \%$, while only $11 \%$ of the control animals survived $(P<0.05)$. Most of the animals died between days 5 and 12 of the follow-up. No differences in the outgrowth of $K$. pneumoniae in the organs and blood of the two mouse strains were found (Table II). LPS plasma concentrations were similar in both mouse strains (Table III). The LPS determinations were performed after heating the plasma, a process which liberates lipoprotein-bound LPS, and thus the total plasma LPS rather than the free LPS concentrations were assessed. Compared with i.v. infection, the LPS concentrations during the i.m. infection were lower $90 \mathrm{~min}$ after infection, but higher at $4 \mathrm{~h}$. This was also accompanied by later increases in cytokines: TNF $\alpha$ and IL-1 $\alpha$ plasma concentrations in most of the samples after 90 min were below the detection limit, to become detectable at $4 \mathrm{~h}$. At the latter time point, a tendency towards decreased circulating concentrations of TNF $\alpha(101 \pm 89$

Table I. Plasma Cholesterol Concentrations (mmol/liter) before and after LPS Challenge and K. pneumoniae Infection in LDLR-/- and C57B1/6J Mice

\begin{tabular}{lccc}
\hline & & LDLR $-1-$ & C57B1/6J \\
\hline Before infection & & $9.55 \pm 1.11$ & $2.25 \pm 0.45^{*}$ \\
After LPS & $90 \mathrm{~min}$ & $5.16 \pm 1.53$ & $1.42 \pm 0.27^{*}$ \\
& $4 \mathrm{~h}$ & $4.10 \pm 0.69$ & $1.42 \pm 0.18^{\S}$ \\
After K. pneumoniae & $90 \mathrm{~min}$ & $5.72 \pm 1.05$ & $1.78 \pm 0.08^{*}$ \\
& $4 \mathrm{~h}$ & $6.27 \pm 1.16$ & $1.96 \pm 0.17^{\S}$ \\
& $24 \mathrm{~h}$ & $7.42 \pm 0.63$ & $2.54 \pm 0.71^{*}$
\end{tabular}

LDLR - / - and control mice were challenged with LPS (1 mg/mouse) or infected i.v. with $10^{6} \mathrm{cfu}$ of $K$. pneumoniae. Each figure represents mean \pm SD of five mice. ${ }^{*} P<0.01 .{ }^{\S} P<0.05$ (for comparison between C57B1/6J and LDLR-/-).
Table II. Bacterial Outgrowth in the Organs of LDLR-/- and C57B1/6J Mice 24 h after i.v. and i.m. Infection with $10^{6} \mathrm{CFU}$ K. pneumoniae*

\begin{tabular}{llll}
\hline & & LDLR-/- & C57B1/6J \\
\hline K. pneumoniae i.v. & Liver & $5.78 \pm 1.09$ & $5.32 \pm 1.30$ \\
& Spleen & $5.72 \pm 1.04$ & $6.40 \pm 1.02$ \\
& Kidneys & $4.83 \pm 1.53$ & $5.32 \pm 1.55$ \\
& Blood & $4.63 \pm 1.19$ & $5.04 \pm 1.00$ \\
& & & \\
K. pneumoniae i.m. & Liver & $5.50 \pm 1.08$ & $5.25 \pm 0.71$ \\
& Spleen & $5.52 \pm 1.57$ & $5.47 \pm 0.86$ \\
& Kidneys & $5.42 \pm 1.46$ & $5.10 \pm 0.49$ \\
& Blood & $4.97 \pm 0.93$ & $5.12 \pm 1.15$ \\
& & & \\
\hline
\end{tabular}

*The data represent mean $\pm \mathrm{SD}$ of log CFU/gram of tissue for five animals. The results do not differ significantly for the three organs and the blood tested.

vs. $235 \pm 228 \mathrm{pg} / \mathrm{mL}, P>0.05)$ and IL- $1 \alpha(35 \pm 12$ vs. $85 \pm 52 \mathrm{pg} /$ $\mathrm{ml}, P>0.05)$ was observed in the LDLR $-/-$ mice when compared with controls, although statistical significance was not reached. IL-1 $\beta$ concentrations were below detection limit both $90 \mathrm{~min}$ and $4 \mathrm{~h}$ after infection.

Ex vivo cytokine production capacity. To investigate whether the decreased in vivo cytokine production by the LDLR-/mice was due to reduced cellular production capacity, rather than to LPS binding and neutralization by the high lipoprotein concentrations, resident peritoneal macrophages were stimulated in vitro by LPS in the absence of plasma or serum. Somewhat surprisingly, cytokine concentrations in supernatants of macrophages from LDLR-/- mice were 2-3-fold higher after LPS stimulation when compared with $\mathrm{C} 57 \mathrm{Bl} / 6 \mathrm{~J}$ mice (Fig. $4 a$ ). The cell-associated TNF $\alpha$ did not differ between the two mouse strains, while both cell-associated IL- $1 \alpha$ and IL- $1 \beta$ were increased in LDLR-/- mice (Fig. 4 b). This increased cytokine production capacity was observed only after LPS stimulation, and was not detected after stimulation with heat-killed Staphylococcus aureus (Fig. 4, $a$ and $b$ ).

Binding of tritiated LPS to peritoneal macrophages. To test whether the increased cytokine production capacity was due to increased LPS binding to macrophages, we assessed the specific binding of [ ${ }^{3} \mathrm{H}$-LPS] to the peritoneal macrophages of the two mouse strains. The specific binding of radiolabeled LPS to the peritoneal macrophages of LDLR $-/-$ mice was signifi-

Table III. LPS Circulating Concentrations $(\mathrm{ng} / \mathrm{mL})$ in LDLR-/- and C57B1/6J Mice after i.v. and i.m. Infection with $10^{6}$ CFU K. pneumoniae*

\begin{tabular}{lccc}
\hline & & LDLR-/- & C57B1/6J \\
\hline K. pneumoniae i.v. & $90 \mathrm{~min}$ & $6.7(3.9-30.5)$ & $25.7(3.5-39.9)$ \\
& $4 \mathrm{~h}$ & $2.9(1.5-4.2)$ & $7.2(3.8-28.7)^{\S}$ \\
K. pneumoniae i.m. & $90 \mathrm{~min}$ & $2.3(0.1-49.2)$ & $3.9(1.7-9.0)$ \\
& $4 \mathrm{~h}$ & $13.4(1.6-26.0)$ & $15.6(1.9-81.5)$
\end{tabular}

* The results represent median (interval) of groups of five mice. ${ }^{8} \mathrm{P}<$ 0.05 (for comparison between LDLR-/- and C57B1/6J mice). Total LPS plasma concentrations were detected after heating the samples, a process which liberates lipoprotein-bound LPS. 


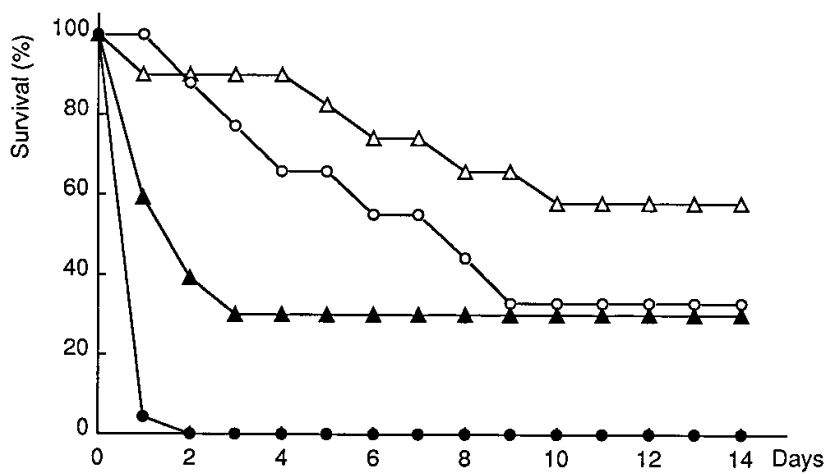

Figure 3. Survival of LDLR-/- and C57Bl/6J mice after i.v. infection with Klebsiella pneumoniae. An i.v. injection of $10^{7} \mathrm{CFU} K$. pneumoniae was given to LDLR - / - (closed triangles) and C57Bl/6J mice (closed circles). Other groups of LDLR $-1-$ (open triangles) and $\mathrm{C} 57 \mathrm{~B} 1 / 6 \mathrm{~J}$ mice (open circles) received $10^{6} \mathrm{CFU}$ K. pneumoniae. Survival was significantly improved in LDLR $-/-$ mice. The figure gives pooled data of three experiments with at least 18 mice per group each.

cantly higher than to macrophages of $\mathrm{C} 57 \mathrm{Bl} / 6 \mathrm{~J}$ mice, after various amounts of ${ }^{3} \mathrm{H}$-LPS added: $2001 \pm 318$ vs. $1132 \pm 222 \mathrm{cpm}$ bound when $10,000 \mathrm{cpm}{ }^{3} \mathrm{H}$-LPS were added $(P<0.05)$; $5806 \pm 442$ vs. $2421 \pm 476 \mathrm{cpm}$ bound $(30,000 \mathrm{cpm}$ added $)(P<$ $0.05)$; and $15,840 \pm 3,305$ vs. $5,901 \pm 368 \mathrm{cpm}$ bound $(100,000$ cpm added) $(P<0.05)$. The non-specific binding of tritiated LPS did not differ between the two mouse strains.

\section{Discussion}

In this study we showed that LDL receptor deficient mice were protected against lethal endotoxemia as well as against severe infections with Gram-negative microorganisms, not only after acute i.v. infection, but also in a more subacute model of intramuscular infection with Klebsiella pneumoniae. Lipoprotein concentrations in the LDLR-/- mice are genetically elevated, due to increased IDL and LDL (22). Our approach thus differs from other models in which exogenous lipoproteins were administered to obtain hyperlipoproteinemia $(10,11,18)$. This intervention was associated with decreased cytokinemia and improved survival during lethal endotoxemia. The same protection was reported in mice in which endogenously elevated HDL were responsible for the increased lipoproteins (19). The importance of endogenous lipoproteins in the protection against lethal endotoxemia was also observed by Feingold and colleagues (20), who reported increased LPSinduced mortality when serum lipids were decreased by pharmacological agents. However, our study shows that the protection due to increased endogenous LDL can be extended to severe Gram-negative infections with live microorganisms.

In general, mortality to infection is considered to be due to lethal cytokinemia or to functional impairment by excessive growth of microorganisms in the organs of the host. In the model of infection we studied, showing no difference in the number of circulating bacteria or the number of bacteria in the tissues, the protection was probably achieved through the high levels of LDL in the LDLR-/- mice, which are able to neutralize the effects of LPS released by similar bacterial loads as in the control mice, and consequently inhibit the induction of lethal
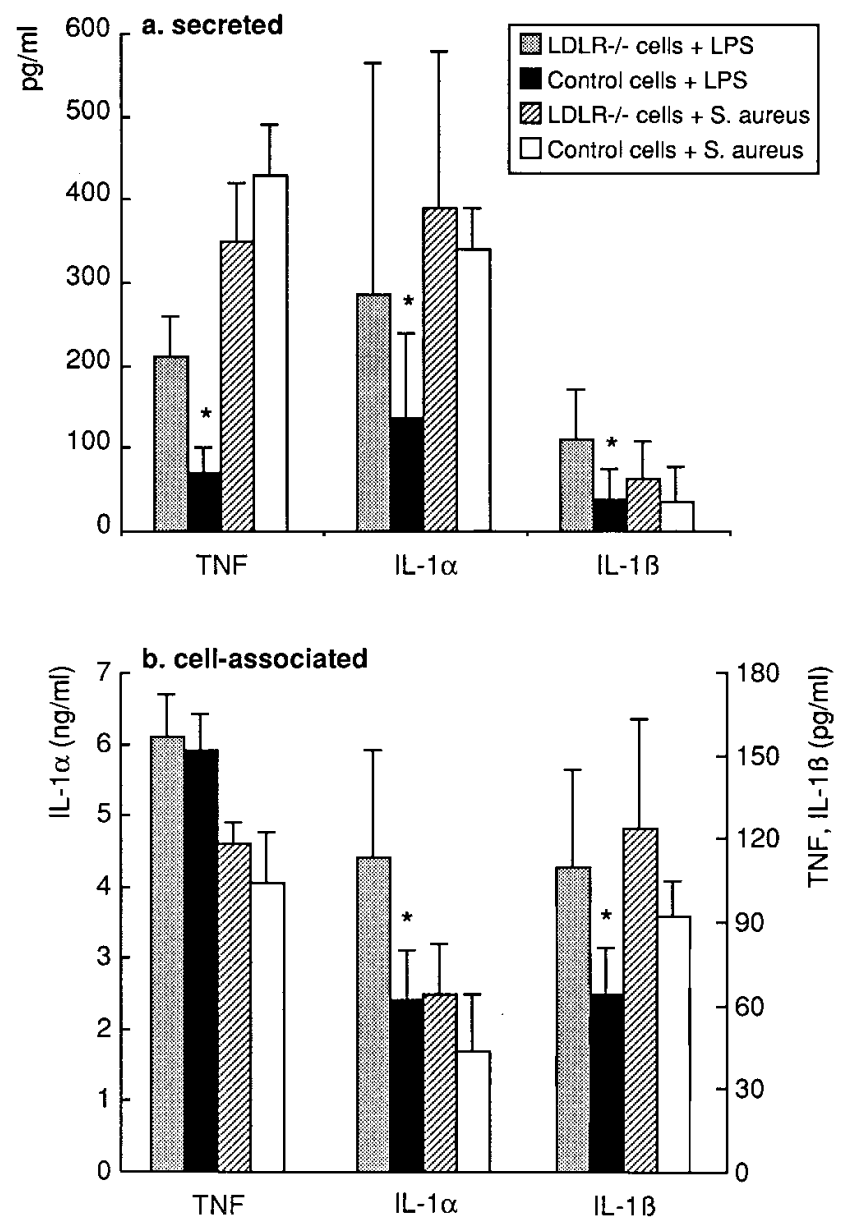

Figure 4. Secreted (Fig. $4 a$ ) and cell-associated (Fig. $4 b$ ) cytokine production after in vitro stimulation of peritoneal macrophages of LDLR $-/-$ and control mice. $10^{5}$ peritoneal macrophages/well were stimulated with either LPS $(1 \mu \mathrm{g} / \mathrm{ml})$ or heat-killed S. aureus $\left(10^{6}\right.$ $\mathrm{CFU} /$ well) for $24 \mathrm{~h}$ at $37^{\circ} \mathrm{C}$. $* P<0.05$ (for comparison between LDLR $-/$ - and control macrophages).

concentrations of cytokines. The crucial role of cytokines in the response to a Gram-negative infection, independently of the bacterial load, has also been documented in our previous studies $(29,30)$.

The protection against the LPS component of Gram-negative bacteria by lipoproteins is achieved either by direct neutralization of LPS by forming LPS-lipoprotein complexes (8, $9,10)$, or by accelerating the clearance of LPS by lipoproteins (11). In this respect, we considered if in our study an increased clearance of LPS or the direct neutralization of LPS by lipoproteins is playing the main role in the protection of LDLR-/mice during $K$. pneumoniae infection. The LPS concentrations tended to be lower in LDLR-/- mice than in controls when the infection was induced by i.v. injection of K. pneumoniae. This may be due to increased LPS clearance, since we determined the LPS concentrations after heating the plasma before the assay, a procedure which liberates lipoprotein-bound LPS (31). However, in the i.m. K. pneumoniae infection model, the LPS concentrations were similar in the LDLR $-/-$ and control mice. Since LDLR-/- mice in this model also showed decreased circulating cytokines, as well as decreased mortality 
compared with control mice, we conclude that probably the main mechanism of protection of LDLR-/- mice in K. pneumoniae infection is through direct binding and neutralization of LPS by lipoproteins, rather than increased clearance of endotoxin. This is not surprising since the clearance of LDL, which is the main lipoprotein fraction increased in the LDLR $-/-$ mice, is decreased in these mice (22), due to the lack of the receptor.

The increased cytokine concentrations in the circulation during Gram-negative infections are thought to be induced by the LPS component of the cell wall. We have shown that LDLR $-/-$ mice were more LPS tolerant, the LPS $\mathrm{LD}_{50}$ in LDLR - / - mice being increased approximately eightfold. Associated with the increased protection of LDLR-/- mice we observed decreased concentrations of the pro-inflammatory cytokines TNF $\alpha$ and IL- $1 \alpha$. The LDLR-/- mice were not protected against a lethal injection of these cytokines, arguing against a direct inactivation of circulating cytokines by lipoproteins, and against decreased peripheral sensitivity of LDLR-/mice to TNF $\alpha$ or IL-1. This confirms that the protection of LDLR $-/-$ mice in lethal endotoxemia is due to an inactivation of the bacterial LPS by increased plasma lipoproteins, which in turn results in a blunted response of the proinflammatory cytokines.

An interesting observation was made when we evaluated the in-vitro cytokine production capacity of the LDLR-/mice. We showed that, in contrast to the in-vivo decreased cytokine production after LPS challenge, the in-vitro LPSstimulated cytokine production capacity of peritoneal macrophages of mice with hypercholesterolemia was higher than in control mice. This increase was observed for all the cytokines tested: TNF $\alpha$, IL- $1 \alpha$ and IL-1 $\beta$. An explanation for these findings could be up-regulation of LPS receptors on the macrophages of LDLR - /- mice. Indeed, our LPS-binding experiments showed increased specific binding of tritiated LPS to the macrophages of LDLR $-/-$ mice. In normal mice, exposure to small LPS quantities may down-regulate its own receptors on the host cells, as has been shown for the CD14 molecule on human cells (32). We hypothesize that in the LDLR-/- mice, such down-regulation of LPS receptors may not occur because the enhanced plasma lipoproteins rapidly bind and neutralize the circulating endotoxin. In our experiments, stimulation with $S$. aureus did not induce an enhanced cytokine production by the macrophages of LDLR-/- mice, suggesting a selective down-regulation of LPS-receptors. Still, a direct effect of the high lipoprotein concentrations on the LPS receptors and LPS binding cannot be excluded, since others have shown that cholesterol modulates CD14 expression on human cells (33), and the clustering of other glycophospholipid-anchored receptors (34). Because LPS binds not only to CD14, but also to CD11b/ CD18, to the scavenger receptor, and possibly other membrane proteins, it remains to be elucidated which of these receptors and mechanisms contributed to the increased LPS binding.

An increased cytokine production capacity has also been observed in monocytes of patients with familial hypercholesterolemia (35) and in individuals with high plasma HDL concentrations (36). The results of these studies and our present findings argue for a more general phenomenon of increased cytokine production by monocytes/macrophages of hosts with high circulating lipoprotein concentrations. The clinical importance of this phenomenon remains to be further studied.

\section{Acknowledgments}

The authors thank Dr. Robert Sauerwein and Jeanette Mulder for performing the endotoxin determinations, and Margo van den Brink, Monique Bakker and Piet Spaan for their excellent assistance with the animal experiments.

\section{References}

1. Lynn, W.A., and J. Cohen. 1995. Adjunctive therapy for septic shock: a review of experimental approaches. Clin. Infect. Dis. 20:143-158.

2. Beutler, B., I.W. Milsark, and A.C. Cerami. 1985. Passive immunization against cachectin/tumor necrosis factor protects mice from lethal effect of endotoxin. Science (Wash. DC). 229:869-871.

3. Tracey, C.J., Y. Fong, D.G. Hesse, K.R. Manogue, A.T. Lee, G.C. Kuo, S.F. Lowry, and A. Cerami. 1987. Anti-cachectin/TNF monoclonal antibodies prevent septic shock during lethal bacteraemia. Nature (Lond.). 330:662-664.

4. Ashkenazi, A., S.A. Marsters, D.J. Capon, S.M. Chamow, I.S. Figari, D. Pennica, D.V. Goeddel, M.A. Palladino, and D.H. Smith. 1991. Protection against endotoxin shock by a tumor necrosis factor immunoadhesin. Proc. Natl. Acad. Sci. USA. 88:10535-10539.

5. Wakabayashi, G., J.A. Gelfand, J.F. Burke, R.C. Thomson, and C.A. Dinarello. 1991. A specific receptor antagonist for interleukin-1 prevents Escherichia coli-induced shock in rabbits. FASEB J. 5:338-343.

6. Mathison, J., P. Tobias, E. Wolfson, and R. Ulevitch. 1991. Regulatory mechanisms of host responsiveness to endotoxin (lipopolysaccharide). Pathobiology. 59:185-188.

7. Pugin, J., C.C. Schurer-Maly, D. Leturcq, A. Moriarty, R.J. Ulevitch, and P.S. Tobias. 1993. Lipopolysaccharide activation of human endothelial and epithelial cells is mediated by lipopolysaccharide-binding protein and soluble CD14. Proc. Natl. Acad. Sci. USA. 90:2744-2751.

8. Wurfel, M.M., S.N. Kunitake, H. Lichenstein, J.P. Kane, and S.D Wright. 1994. Lipopolysaccharide (LPS)-binding protein is carried on lipoproteins and acts as a cofactor in the neutralization of LPS. J. Exp. Med. 180:10251035.

9. Wurfel, M.M., E. Heilman, and S.D. Wright. 1995. Soluble CD14 acts as a shuttle in the neutralization of lipopolysaccharide (LPS) by LPS-binding protein and reconstituted high density lipoprotein. J. Exp. Med. 181:1743-1754.

10. Ulevitch, R.J., and A.R. Johnston. 1978. The modification of biophysical and endotoxic properties of bacterial lipopolysaccharides by serum. J. Clin. Invest. 62:1313-1324.

11. Van Lenten, B.J., A.M. Fogelman, M.E. Haberland, and P.A. Edwards. 1986. The role of lipoproteins and receptor-mediated endocytosis in the transport of bacterial lipopolysaccharide. Proc. Natl. Acad. Sci. USA. 83:2704-2708.

12. Harris, H.W., C. Grunfeld, K.R. Feingold, and J.H. Rapp. 1990. Human very low density lipoproteins and chylomicrons can protect against endotoxininduced death in mice. J. Clin. Invest. 86:696-702.

13. Harris, H.W., C. Grunfeld, K.R. Feingold, T.E. Read, J.P. Kane, A.L. Jones, E.B. Eichbaum, G.F. Bland, and J.H. Rapp. 1993. Chilomicrons alter the fate of endotoxin, decreasing tumor necrosis factor release and preventing death. J. Clin. Invest. 91:1028-1034.

14. Tahri-Jouti, R.A., and R. Chabi. 1991. Binding of endotoxin to macrophages: distinct effects of serum constituents. Immunol. Invest. 20:377-386.

15. Munford, R.S., J.M. Andersen, and J.M. Dietsliy. 1981. Sites of tissue binding and uptake in vivo of bacterial lipopolysaccharide-high density lipoprotein complexes. J. Clin. Invest. 68:1503-1513.

16. Flegel, W.A., A. Wolpl, D.N. Mannel, and H. Northoff. 1989. Inhibition of endotoxin-induced activation of human monocytes by human lipoproteins. Infect. Immun. 57:2237-2245.

17. Warren, H.S., G.R. Riveau, F.A. de Deckker, and L.A. Chedid. 1988. Control of endotoxin activity and interleukin-1 production through regulation of lipopolysaccharide-lipoprotein binding by a macrophage factor. Infect. Immun. 56:204-212.

18. Hubsch, A.P., F.S. Powell, P.G. Lerch, and J.E. Doran. 1993. A reconstituted, apolipoprotein A-1 containing lipoprotein reduces tumor necrosis factor release and attenuates shock in endotoxemic rabbits. Circulatory Shock. 40:1423.

19. Levine, D.M., T.S. Parker, T.M. Donelly, A. Walsh, and A.L. Rubin. 1993. In vivo protection against endotoxin by plasma high density lipoprotein. Proc. Natl. Acad. Sci. USA. 90:12040-12044.

20. Feingold, K.R., J.L. Funk, A.H. Moser, J.K. Shigenaga, J.H. Rapp, and C. Grunfeld. 1995. Role for circulating lipoproteins in protection from endotoxin toxicity. Infect. Immun. 63:2041-2046.

21. Read, T.E., C. Grunfeld, Z.L. Kumwenda, M.C. Calhoun, J.P. Kane, K.R. Feingold, and J.H. Rapp. 1995. Triglyceride-rich lipoproteins prevent septic death in rats. J. Exp. Med. 182:267-272.

22. Ishibashi, S., M.S. Brown, J.L. Goldstein, R.D. Gerard, R.E. Hammer, and J. Herz. 1993. Hypercholesterolemia in low density lipoprotein receptor knockout mice and its reversal by adenovirus-mediated gene delivery. J. Clin. Invest. 92:883-893. 
23. Netea, M.G., W.L. Blok, B.J. Kullberg, M. Bemelmans, M.T.E. Vogels, W.A. Buurman, and J.W.M. van der Meer. 1995. Pharmacologic inhibitors of tumor necrosis factor production exert differential effects in lethal endotoxemia and in infection with live microorganisms in mice. J. Infect. Dis. 171:393399.

24. Vogels, M.T.E., E.J.B.M. Mensink, K. Ye, O.C. Boerman, C.M.M. Verschueren, C.A. Dinarello, and J.W.M. van der Meer. 1994. Differential gene expression for interleukin-1 receptor antagonist, interleukin-1 (IL-1) and tumor necrosis factor (TNF) receptors and IL-1 and TNF synthesis may explain interleukin-1-induced resistance to infection J. Immunol. 153:5772-5780.

25. Watson, J., and R. Riblet. 1975. Genetic control of responses to bacterial lipopolysaccharides in mice. J. Immunol. 114:1462-1468.

26. Cavaillon, J.M., C. Fitting, N. Haeffner-Cavaillon, S.J. Kirsch, and H.S. Warren. 1990. Cytokine response by monocytes and macrophages to free and lipoprotein-bound lipopolysaccharide. Infect. Immun. 58:2375-2382.

27. Peto, R., M.C. Pike, P. Armitage, N.E. Breslow, D.R. Cox, V. Howard, N. Mantel, K. McPherson, J. Peto, and P.G. Smith. 1977. Design and analysis of randomized clinical trials requiring prolonged observation of each patient. $\mathrm{Br}$. J. Cancer. 35:1-39.

28. Kalbfleisch, J.D., and R.L. Prentice. 1980. The statistical analysis of failure time data. John Wiley \& Sons, Inc., New York.

29. Van der Meer, J.W.M. 1988. The effects of recombinant interleukin-1 and recombinant tumor necrosis factor on non-specific resistance to infection. Biotherapy. 1:19-25.
30. Van der Meer, J.W.M., M. Barza, S.M. Wolff, and C.A. Dinarello. 1988. A low dose of recombinant interleukin-1 protects granulocytopenic mice from lethal Gram-negative infection. Proc. Natl. Acad. Sci. USA. 85:1620-1623.

31. Eichbaum, E.B., H.W. Harris, J.P. Kane, and J.H. Rapp. 1991. Chylomicrons can inhibit endotoxin activity in vivo. J. Surg. Res. 51:413-416.

32. Basil, V., and J.L. Strominger. 1991. Shedding as a mechanism of downmodulation of CD14 on stimulated human monocytes. J. Immunol. 147:15671574.

33. Esfahani, M., R.D. Bigler, J.L. Alfieri, S. Lund-Katz, J.D. Baum, and L. Scerbo. 1993. Cholesterol regulates the cell surface expression of glycophospholipid-anchored CD14 antigen on human monocytes. Biochim. Biophys. Acta. 1149:217-223.

34. Rothberg, K.G., Y.S. Ying, B.A. Kamen, and R.G.W. Anderson. 1990. Cholesterol controls the clustering of the glycophospholipid-anchored membrane receptor for 5-methyltetrahydrofolate. J. Cell. Biol. 111:2931-2938.

35. Leirisalo-Repo, M., M. Jaattela, H. Gylling, T.A. Miettinen, and H. Repo. 1990. Phagocyte function in familial hypercholesterolemia: peripheral blood monocytes exposed to lipopolysaccharide show increased tumour necrosis factor production. Scand. J. Immunol. 32:679-685.

36. Eggesbo, J.B., I. Hjermann, P.K. Lund, G.B. Joo, R. Ovstebo, and P. Kierulf. 1994. LPS-induced release of IL-1 $\beta$, IL-6, IL-8, TNF $\alpha$ and sCD14 in whole blood and PBMC from persons with high or low levels of HDL-lipoprotein. Cytokine. 6:521-529. 